\title{
ANALIZA UTJECAJA PET PORTEROVIH SILA NA KONKURENTNOST HRVATSKIH IZVOZNIH PODUZEĆA
}

\author{
Dr. sc. Kristijan Marić, viši predavač \\ Sveučilište Libertas \\ Trg J. F. Kennedy 6 b, 10000 Zagreb, Hrvatska \\ Telefon: +385 91 3888-305, e-mail: kristijan.maric1@gmail.com
}

\section{SAŽETAK}

$U$ ovom radu problematizira se konkurentnost hrvatskoga gospodarstva. U teorijskim poglavljima rada, na temelju sekundarnih izvora podataka prikupljenih "desk" metodom (istraživanje za stolom), prikazana je konkurentnost hrvatskoga gospodarstva i koncept pet konkurentskih sila prema Porteru. U tu svrhu korištena je znanstvena i stručna literatura te Internetski izvori. Uz sekundarne, u radu su prikazani i primarni rezultati istraživanja, koji predstavljaju odgovore ispitanika prikupljene metodom internetske ankete. Ispitanike su predstavljali zaposlenici hrvatskih izvoznih poduzeća, a njihovi odgovori obrađeni su metodom deskriptivne statističke analize. S tim u vezi, cilj istraživanja u ovom radu predstavlja rangiranje utjecaja Porterovih pet sila na konkurentnost hrvatskih izvoznih poduzeća, što je provedeno statističkom analizom varijanci. Predmetno istraživanje tj. sekundarni i primarni podatci prikazani u ovom radu preuzeti su iz doktorske disertacije autora ovog rada.

Ključne riječi: pet Porterovih sila, globalna konkurentnost; konkurentnost Hrvatske; hrvatski izvoznici 


\section{UVOD}

Konkurentnost hrvatskoga gospodarstva već godinama stagnira, što dokazuju i rezultati analize Nacionalnog vijeća za konkurentnost, prema kojima je Hrvatska svrstana na 60. mjesto od ukupno 63 analizirane zemlje. To znači da je Hrvatska konkurentnija samo od Argentine, Mongolije i Venecuele, što predstavlja problem istraživanja ovog rada. Shodno navedenom, rast izvoza predstavlja jedan od modela za podizanje konkurentnosti. S druge strane, kako bi se rast izvoza i ostvario, Hrvatska izvozna poduzeća konkontinuirano trebaju podizati vlastitu konkurentnost. S tim u vezi, u ovom radu predstavljen je koncept pet konkurentskih sila prema Porteru, koje utječu na konkurentnost poduzeća. To su sile koje poduzeće treba internim resursima preoblikovati u svoju korist, a iste predstavljaju predmet istraživanja u ovom radu.

Prema tome, rezultati istraživanja prikazani u istraživačkom poglavlju ukazat će koju razinu utjecaja na Hrvatska izvozna poduzeća ima svaka od pet Porterovih sila. Nadalje, rezultati će se rangirati sukladno čemu će se otkriti koje dvije konkurentske sile imaju najznačajniji utjecaj na konkurentnost hrvatskih izvoznih poduzeća, što predstavlja cilj ovog rada.

\subsection{Metode, izvori istraživanja i metodologija}

Sukladno definiranom problemu, predmetu i cilju istraživanja, u radu su na temelju sekundarnih izvora podataka analizirani podaci dostupni u znanstvenoj i stručnoj literaturi te Internetu koji upućuju na spoznaje o istraživačkoj temi te je na temelju razvijenih teorijskih tvrdnji pristupljeno deduktivnom zaključivanju. Navedeni sekundarni podaci prikupljeni su istraživanjem za stolom („desk“ metoda), a korišteni su za prikaz koncepta konkurentnosti prema Porteru i za prikaz razine konkurentnosti hrvatskoga gospodarstva. Uz teorijska, ovaj rad sadrži i istraživačko poglavlje, u kojem su korišteni primarni podatci prikupljeni putem internetske ankete, koja je izrađena korištenjem informatičkog programa Google Forms. Poveznica (link) na internetsku anketu upućena je elektroničkom poštom na adrese 380 poduzeća. Anketni upitnik ispunilo je 133 ispitanika iz 133 izvozna poduzeća koja su registrirana u Republici Hrvatskoj.

Za prikaz i formuliranje rezultata empirijskog istraživanja korištene su različite znanstveno-istraživačke metode kao što su: metoda anketiranja, metoda analize, metoda komparacije i metoda sinteze. Uz navedene, korištena je i metoda statističke analize prilikom izrade istraživačkog poglavlja ovog rada. U statističkoj analizi odgovora na anketna pitanja izračunavani su osnovni pokazatelji deskriptivne statistike: aritmetička sredina, standardna devijacija, koeficijent asimetrije i koeficijent varijabilnosti. Rezultati statističke obrade dobivenih podataka prikazani su tablično i grafički. Za statističku analizu podataka korišten je računalni program MS Excel. Metodom deskriptivne statističke analize odgovora ispitanika iz ankete analiziran je utjecaj pet Porterovih sila na konkurentnost hrvatskih izvoznih poduzeća, dok je rangiranje važnosti svake od pet Poterovih sila provedeno statističkom analizom varijanci (Analysis of variance Analysis of means using variance). 


\subsection{Hipoteze rada}

Hipoteza H1: Hrvatski su izvoznici spremni ulaganjem vlastitih resursa podizati konkurentnost kako bi promijenili u svoju korist one konkurentske sile koje ih čine nedovoljno konkurentnima.

Hipoteza H2: Promjenom konkurentske sile pregovaračka moć kupaca u svoju korist, hrvatski izvoznici omogućuju podizanje konkurentnosti svojih poduzeća.

Hipoteza H3: Promjenom konkurentske sile rivalitet među postojećim poduzećima u svoju korist, hrvatski izvoznici omogućuju podizanje konkurentnosti svojih poduzeća.

\subsection{Svrha i znanstveni doprinos}

Svrha provedenog istraživanja u ovom radu predstavlja teorijski i praktični doprinos razumijevanju povezanosti pet Porterovih konkurentskih sila i podizanja konkurentnosti hrvatskih izvoznika. Shvaćanjem svrhe istraživanja, pregledom dokazivosti hipoteza i rezultata istraživanja te ostvarenjem cilja ovog rada, hrvatski izvoznici trebaju postati motivirani za poduzimanje potrebnih aktivnosti, putem kojih mogu promijeniti najvažnije konkurentske sile u svoju korist, što će omogućiti podizanja konkurentnosti njihovih poduzeća. Znanstveni doprinos ovog rada predstavlja rangiranje pet Porterovih konkurentskih sila prema važnosti utjecaja na konkurentnost hrvatskih izvoznih poduzeća, a zahvaljujući rezultatima istraživanja, hrvatski izvoznici mogu unaprijediti svoje strategije za podizanje konkurentnosti.

\section{PORTEROV MODEL PET KONKURENTSKIH SILA}

Michael E. Porter vodeći je svjetski ekonomist iz područja konkurentnosti poduzeća. U svojim djelima, Porter se uvijek fokusirao na podizanje konkurentnosti, ali i na održivost takvih modela poslovanja. S tim u vezi, u nastavku rada slijedi prikaz pet Porterovih konkurentskih sila te definiranje svake konkurentske sile u odnosu na tržište i prisutne dionike, kao što su kupci, dobavljači i konkurenti. S tim u vezi, konkurentnost predstavlja preduvjet za izlazak poduzeća na inozemna tržišta, dok je izvoz generator razvoja svakog nacionalnog gospodarstva.

Izvozom se ostvaruju devizna sredstva koja mogu posložiti za uvoz deficitarnih (nedostajućih) roba ili proizvoda koji se u vlastitoj zemlji uopće ne proizvode, a radi zadovoljavanja potražnje u zemlji. (Andrijanić, 2012, 6) „Prva temeljna odrednica profitabilnosti poduzeća privlačnost je industrije. Konkurentska strategija mora nastati iz razumijevanja sofisticiranih pravila natjecanja koja određuju privlačnost neke industrije. Krajnji je cilj konkurentske strategije nositi se s tim pravilima, odnosno, u idealnom slučaju, promijeniti ih u svoju korist. U bilo kojoj industriji, bez obzira na to je li domaća ili međunarodna te nudi li proizvod ili uslugu, pravila natjecanja utjelovljena su u pet kompetitivnih sila: ulazak novih sudionika, prijetnja proizvoda supstituta ili usluga, pregovaračka moć kupaca, pregovaračka moć dobavljača i rivalitete među postojećim konkurentima." (Porter, M. (2008). Konkurentska prednost, Masmedia, Zagreb str. 23.-24.) 


\section{Slika 1 Porterovih pet konkurentskih sila}

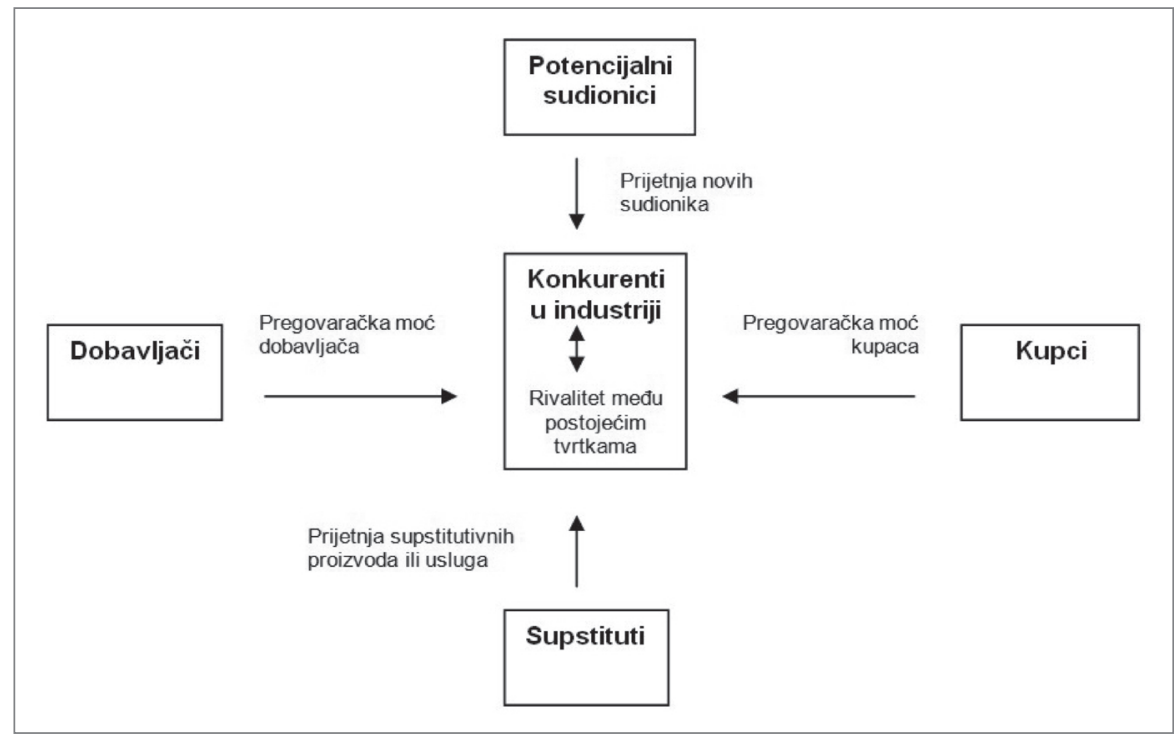

Izvor: Porter, M. (2008). Konkurentska prednost, Masmedia, Zagreb, str. 24.

„Pet konkurentskih sila prikazanih na slici određuju profitabilnost industrije, zato što utječu na cijene, troškove i potrebne investicije poduzeća u industriji - element povrata na investicije. Na primjer, moć kupaca, kao i prijetnja supstituta, utječu na cijene koje poduzeća mogu naplaćivati. Moć kupaca također utječe na troškove i investicije budući da moćniji kupci traže skuplje usluge. Nadalje, pregovaračka moć dobavljača određuje cijenu sirovina i drugih inputa. Intenzitet rivalstva utječe na cijene, ali i troškove nadmetanja u području postrojenja, razvoja proizvoda, oglašavanja i prodaje. Prijetnja ulaska novih sudionika ograničava cijene i oblikuje investicije koje su potrebne za odvraćanje novih sudionika. Snaga svake od tih pet konkurentskih sila (potencijalni sudionici, kupci, dobavljači, supstituti, rivalitet) funkcija je industrijske strukture, odnosno pozadinskih ekonomskih i tehničkih obilježja industrije. Industrijska struktura relativno je stabilna, ali podložna je promjenama kako se industrija razvija. Promjena strukture mijenja apsolutnu i relativnu snagu konkurentskih sila i prema tome može pozitivno ili negativno utjecati na profitabilnost industrije." (Porter, M. (2008). Konkurentska prednost, Masmedia, Zagreb str. 24.-25.)

\section{Prijetnja novih sudionika}

„Ta sila određuje vjerojatnost ulaska novih sudionika, tj. poduzeća (konkurencije) u industriju u kojoj poduzeće posluje i na taj mu način oduzima dio stvorenih vrijednosti. Novi sudionici to mogu postići prenošenjem stvorenih vrijednosti na kupce tako što će spustiti svoje cijene ili povećanjem ulaganja u istraživanje i razvoj te marketing." (Porter, M. (2008). Konkurentska prednost, Masmedia, Zagreb str. 24.-25.) 


\section{Pregovaračka moć kupaca}

„Ta sila utječe na formiranje visine cijena od strane poduzeća, ali i na troškove, razvoj i investicije. Kupci više platežne moći žele kupovati skuplje proizvode i usluge što određuje koliko će stvorene vrijednosti poduzeća kupci zadržati za sebe, a koliko će stvorene vrijednosti ostati poduzećima za daljnju proizvodnju, rast i razvoj." (Porter, M. (2008). Konkurentska prednost, Masmedia, Zagreb str. 24.-25.)

\section{Pregovaračka moć dobavljača}

„Ta sila utječe na cijenu sirovina i ostalih potrebnih inputa što određuje koliko će stvorene vrijednosti za kupce preuzeti dobavljači, a koliko će stvorene vrijednosti ostati poduzeću." (Porter, M. (2008). Konkurentska prednost, Masmedia, Zagreb str. 24.-25.)

\section{Prijetnja proizvoda supstituta}

„Ta sila određuje do koje mjere neki drugi proizvod može zamijeniti iste potrebe kupaca te na taj način postavlja gornju granicu koju je kupac voljan platiti za proizvod neke industrije i predstavlja sklonost kupaca prema drugim proizvodima što dovodi do oduzimanja dijela stvorene vrijednosti industriji u kojoj poduzeće posluje." (Porter, M. (2008). Konkurentska prednost, Masmedia, Zagreb str. 24.-25.)

\section{Rivalitet među postojećim poduzećima}

„Ta sila utječe na određivanje i postizanje cijena, ali i na troškove koji dolaze kao posljedica nadmetanja s konkurencijom, a to je područje unaprjeđenja tehnološki naprednih postrojenja, razvoj novih proizvoda te prodaja i marketing. Također, rivalitet među postojećim poduzećima ima sličan utjecaj kao i prijetnja ulaska novih sudionika u industriju, osim što određuje do koje će se mjere postojeća poduzeća u industriji međusobno natjecati za prisvajanje dijela vrijednosti koju su stvorile za kupce, prenoseći je na kupce nižim cijenama ili rasipanjem kroz više troškove natjecanja." (Porter, M. (2008). Konkurentska prednost, Masmedia, Zagreb str. 24.-25.)

\section{KONKURENTNOST HRVATSKOGA GOSPODARSTVA}

Institut za razvoj poslovnog upravljanja iz Lausanne čiji je partner Nacionalno vijeće za konkurentnost, objavio je rezultate Godišnjaka svjetske konkurentnosti 2019. Hrvatska je u ovogodišnjem izvješću zauzela 60. od ukupno 63 mjesta na ljestvici svjetske ekonomije, što je rast za jedno mjesto u odnosu na prethodnu godinu. 
Tablica 1. Globalna konkurentnost zemalja 2018. - 2019.

\begin{tabular}{|c|c|c|c|}
\hline $\begin{array}{l}\text { WCY } \\
2019\end{array}$ & Zemlja & $\begin{array}{l}\text { WCY } \\
2018\end{array}$ & Promjena \\
\hline 1 & Singapur & 3 & +2 \\
\hline 2 & Hong Kong & 2 & 0 \\
\hline 3 & SAD & 1 & -2 \\
\hline 4 & Švicarska & 5 & +1 \\
\hline 5 & UAE & 7 & +2 \\
\hline 6 & Nizozemska & 4 & -2 \\
\hline 7 & Irska & 12 & +5 \\
\hline 8 & Danska & 6 & -2 \\
\hline 9 & Švedska & 9 & 0 \\
\hline 10 & Katar & 14 & +4 \\
\hline 11 & Norveška & 8 & -3 \\
\hline 12 & Luksemburg & 11 & -1 \\
\hline 13 & Kanada & 10 & -3 \\
\hline 14 & Kina & 13 & -1 \\
\hline 15 & Finska & 16 & +1 \\
\hline 16 & Tajvan, Kina & 17 & +1 \\
\hline 17 & Njemačka & 15 & -2 \\
\hline 18 & Australija & 19 & +1 \\
\hline 19 & Austrija & 18 & -1 \\
\hline 20 & Island & 24 & +4 \\
\hline 21 & Novi Zeland & 23 & +2 \\
\hline 22 & Malezija & 22 & 0 \\
\hline 23 & UK & 20 & -3 \\
\hline 24 & Izrael & 21 & -3 \\
\hline 25 & Tajland & 30 & +5 \\
\hline 26 & Saudijska A. & 39 & +13 \\
\hline 27 & Belgija & 26 & -1 \\
\hline 28 & Koreja & 27 & -1 \\
\hline 29 & Litva & 32 & +3 \\
\hline 30 & Japan & 25 & -5 \\
\hline 31 & Francuska & 28 & -3 \\
\hline 32 & Indonezija & 43 & +11 \\
\hline
\end{tabular}

\begin{tabular}{|c|c|c|c|}
\hline $\begin{array}{l}\text { WCY } \\
2019\end{array}$ & Zemlja & $\begin{array}{l}\text { WCY } \\
2018\end{array}$ & Promjena \\
\hline 33 & Češka & 29 & -4 \\
\hline 34 & Kazahstan & 38 & +4 \\
\hline 35 & Estonija & 31 & -4 \\
\hline 36 & Španjolska & 36 & 0 \\
\hline 37 & Slovenija & 37 & 0 \\
\hline 38 & Poljska & 34 & -4 \\
\hline 39 & Portugal & 33 & -6 \\
\hline 40 & Latvija & 40 & 0 \\
\hline 41 & Cipar & 41 & 0 \\
\hline 42 & Čile & 35 & -7 \\
\hline 43 & Indija & 44 & +1 \\
\hline 44 & Italija & 42 & -2 \\
\hline 45 & Rusija & 45 & 0 \\
\hline 46 & Filipini & 50 & +4 \\
\hline 47 & Mađarska & 47 & 0 \\
\hline 48 & Bugarska & 48 & 0 \\
\hline 49 & Rumunjska & 49 & 0 \\
\hline 50 & Meksiko & 51 & +1 \\
\hline 51 & Turska & 46 & -5 \\
\hline 52 & Kolumbija & 58 & +6 \\
\hline 53 & Slovačka & 55 & +2 \\
\hline 54 & Ukrajina & 59 & +5 \\
\hline 55 & Peru & 54 & -1 \\
\hline 56 & Južna Afrika & 53 & -3 \\
\hline 57 & Jordan & 52 & -5 \\
\hline 58 & Grčka & 57 & -1 \\
\hline 59 & Brazil & 60 & +1 \\
\hline 60 & Hrvatska & 61 & +1 \\
\hline 61 & Argentina & 56 & -5 \\
\hline 62 & Mongolija & 62 & 0 \\
\hline 63 & Venezuela & 63 & 0 \\
\hline
\end{tabular}

Izvor: http://konkurentnost.hr/imd-godisnjak-svjetske-konkurentnosti-2019-stvarni-napredak-zahtijeva-brzei-temeljitije-reforme/ (1.7.2019.) 
Kao što se vidi iz prikazanih rezultata u tablici, osim Irske, zemlje Europske unije nisu 2019. godine postigle osjetan rast konkurentnosti. Što se tiče ukupnog rezultata, Singapur je zauzeo prvo mjesto, skinuvši s trona SAD, koji je pao na treće mjesto, dok je Hong Kong zadržao drugu poziciju, kao i prethodne godine. S druge strane, najlošiji rezultat na ljestvici konkurentnosti, kao i prethodne godine, ostvarile su Venezuela i Mongolija, dok se odmah iza njih nalazi Argentina, koja je pala za pet mjesta. Ispred Argentine nalazi se Hrvatska, koja je rasla za jedno mjesto i nalazi se na šezdesetom mjestu, kao četvrta odostraga, što predstavlja jako loš rezultat. Također, treba naglasiti da je Hrvatska rasla zahvaljujući padu Argentine za pet mjesta.

\section{Grafikon 1 Konkurentnost Republike Hrvatske i usporednih zemalja}

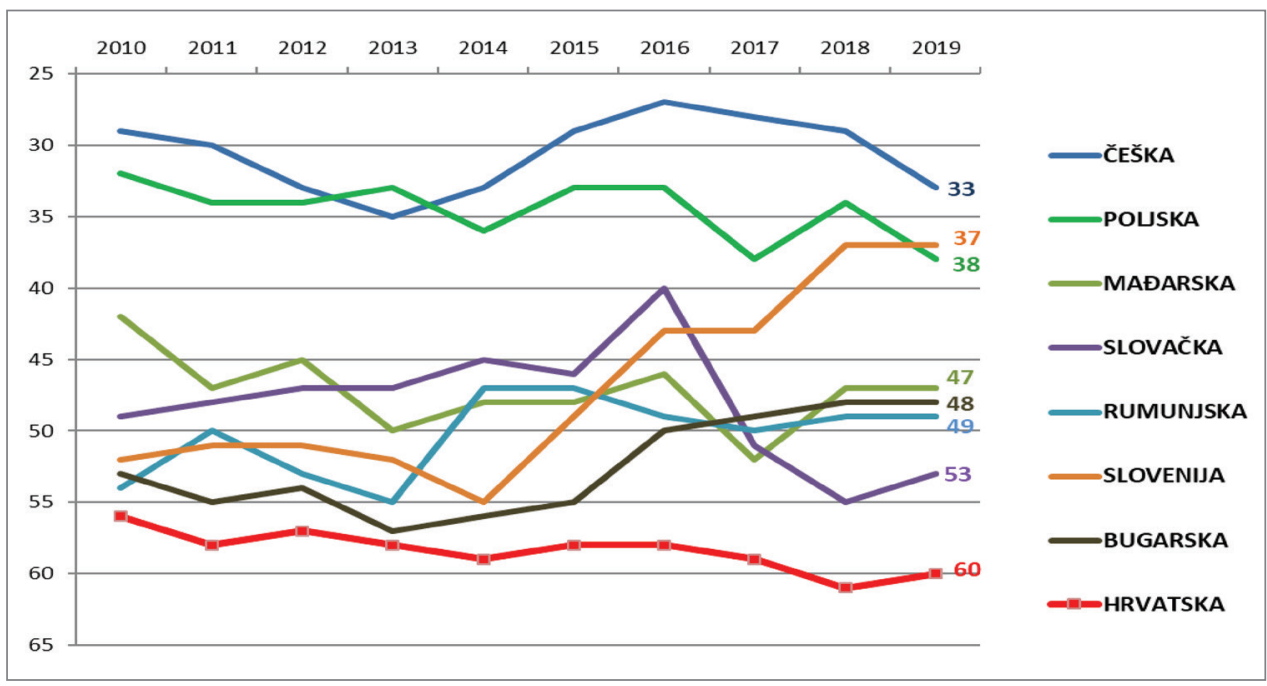

Izvor: http://konkurentnost.hr/imd-godisnjak-svjetske-konkurentnosti-2019-stvarni-napredak-zahtijeva-brzei-temeljitije-reforme/ (1.7.2019.)

Prema IMD-u (Godišnjak svjetske konkurentnosti) prikazana je konkurentnost zemalja u okruženju, od kojih su jedino Slovačka i Hrvatska rasle. Slovačka je rasla za dva mjesta, a Hrvatska je rasla za jedno mjesto, dok su Poljska i Češka ostvarile pad za četiri mjesta u odnosu na prošlu godinu. Ostale zemlje nisu mijenjale svoju poziciju u odnosu na prethodnu godinu 


\section{ISTRAŽIVANJE O VAŽNOSTI PET PORTEROVIH SILA ZA KONKURENTNOST HRVATSKIH IZVOZNIH PODUZEĆA}

U nastavku rada prikazani su rezultati primarnog istraživanja preuzeti iz doktorske disertacije autora ovog rada.

Tablica 2 Sektori gospodarstva u kojima posluju analizirana poduzeća iz ankete empirijskog istraživanja (prema NKD 2007.)

\begin{tabular}{|c|c|c|c|c|c|}
\hline \multicolumn{6}{|c|}{ Pitanje 3.: U kojem sektoru gospodarstva posluje Vaše poduzeće? } \\
\hline & $\begin{array}{c}\text { Promet } \\
<\text { od } \\
10 \text { mil } €\end{array}$ & $\begin{array}{c}\text { Promet } \\
<\text { od } \\
2 \text { mil } €\end{array}$ & $\begin{array}{c}\text { Promet } \\
<\text { od } \\
50 \text { mil } €\end{array}$ & $\begin{array}{c}\text { Promet } \\
>\text { od } \\
50 \text { mil } €\end{array}$ & $\Sigma$ \\
\hline Izvan teritorijalne organizacije i tijela & 1 & 1 & & & 2 \\
\hline Zdravstvena zaštita i socijalna skrb & 1 & & 1 & & 2 \\
\hline Financijske djelatnosti i osiguranje & 1 & 1 & & & 2 \\
\hline Građevinarstvo & 2 & 1 & 2 & 2 & 7 \\
\hline Informacije i komunikacije & 1 & 2 & 4 & 2 & 9 \\
\hline El. energija, plin, para i klimatizacija & & & 1 & & 1 \\
\hline Ostale uslužne djelatnosti & 2 & 2 & 1 & & 5 \\
\hline Poljoprivreda, šumarstvo i ribarst & 2 & 2 & 3 & & 7 \\
\hline Popravak motornih vozila & 1 & & & & 1 \\
\hline Poslovanje nekretninama & & 2 & & & 2 \\
\hline Prerađivačka industrija & 21 & 14 & 13 & 13 & 61 \\
\hline Prijevoz i skladištenje & 4 & 1 & 1 & & 6 \\
\hline Rudarstvo i vađenje & 1 & & & & 1 \\
\hline Stručne, znanstv. i tehničke djelat. & 1 & 3 & & & 4 \\
\hline Trgovina na veliko i na malo & 9 & 4 & 4 & 5 & 22 \\
\hline Umjetnost, zabava i rekreacija & & & & 1 & 1 \\
\hline Ukupno & 47 & 33 & 30 & 23 & 133 \\
\hline
\end{tabular}

Izvor: Marić, K. (2019). Modeli za podizanje izvozne konkurentnosti hrvatskoga gospodarstva, doktorski rad, Sveučilište u Zadru i Sveučilište Libertas, str. 109.

„U tablici je prikazano u kojem sektoru gospodarstva (Prema NKD 2007.) posluju 133 analizirana poduzeća, kako slijedi: izvan teritorijalne organizacije i tijela = 2 poduzeća, djelatnosti zdravstvene zaštite i socijalne skrbi = 2 poduzeća, financijske djelatnosti i djelatnosti osiguranja $=2$ poduzeća, građevinarstvo $=7$ poduzeća, informacije i komunikacije $=9$ poduzeća, opskrba električnom energijom, plinom, parom i klimatizacija = 1 poduzeće, ostale uslužne djelatnosti $=5$ poduzeća, poljoprivreda, šumarstvo i ribarstvo $=7$ poduzeća, popravak motornih vozila i motocikla $=1$ poduzeće, poslovanje nekretninama $=2$ poduzeća, prerađivačka industrija $=61$ poduzeće, prijevoz i skladištenje $=6$ poduzeća, rudarstvo i vađenje = 1 poduzeće, stručne, znanstvene i tehničke djelatnosti $=4$ poduzeća, 
trgovina na veliko i na malo = 22 poduzeća, umjetnost, zabava i rekreacija $=1$ poduzeće. Pivot tablica je višedimenzionalna i u istoj je prikazan odnos između analiziranih poduzeća prema sektoru gospodarstva u kojima poduzeća posluju i njihovog ukupnog prometa.“ (Marić, 2019, 109-110)

Tablica 3 Utjecaj konkurentske sile prijetnja novih sudionika na konkurentnost analiziranih poduzeća iz ankete empirijskog istraživanja

\begin{tabular}{|c|c|c|c|c|c|}
\hline \multicolumn{6}{|c|}{$\begin{array}{l}\text { Pitanje 14.: Konkurentska sila „Prijetnja novih sudionika“ } \\
\text { za konkurentnost mojeg poduzeće ima razinu utjecaja: }\end{array}$} \\
\hline & $\begin{array}{c}\text { Promet } \\
<\text { od } \\
10 \mathrm{mil} €\end{array}$ & $\begin{array}{c}\text { Promet } \\
<\text { od } \\
2 \text { mil } €\end{array}$ & $\begin{array}{c}\text { Promet } \\
<\text { od } \\
50 \mathrm{mil} €\end{array}$ & $\begin{array}{c}\text { Promet } \\
>\text { od } \\
50 \mathrm{mil} €\end{array}$ & $\Sigma$ \\
\hline 1. Iznimno visoka & 7 & 2 & 3 & 1 & 13 \\
\hline Informacije i komunikacije & 1 & & & & 1 \\
\hline Ostal+e uslužne djelatnosti & & & 1 & & 1 \\
\hline Poslovanje nekretninama & & 1 & & & 1 \\
\hline Prerađivačka industrija & 2 & 1 & 1 & 1 & 5 \\
\hline Trgovina na veliko i na malo & 4 & & 1 & & 5 \\
\hline 2. Visoka & 8 & 7 & 8 & 8 & 31 \\
\hline Izvanteritorijalne organiz. i tijela & 1 & 1 & & & 2 \\
\hline Zdravst. zaštita i socijalna skrb & & & 1 & & 1 \\
\hline Građevinarstvo & & & 1 & & 1 \\
\hline Informacije i komunikacije & & & 2 & & 2 \\
\hline Ostale uslužne djelatnosti & & 1 & & & 1 \\
\hline Prerađivačka industrija & 5 & 3 & 4 & 4 & 16 \\
\hline Trgovina na veliko i na malo & 2 & 2 & & 4 & 8 \\
\hline 3. Podjednako visoka i niska & 21 & 22 & 11 & 4 & 58 \\
\hline Zdravst. zaštita i socijalna skrb & 1 & & & & 1 \\
\hline Financijske djelatnosti i osiguranje & & 1 & & & 1 \\
\hline Građevinarstvo & 1 & 1 & 1 & 1 & 4 \\
\hline Informacije i komunikacije & & 2 & 1 & & 3 \\
\hline El. energija, plin, para i klima & & & 1 & & 1 \\
\hline Ostale uslužne djelatnosti & & 1 & & & 1 \\
\hline Poljoprivreda, šumarstvo, ribarstvo & 2 & 2 & 2 & & 6 \\
\hline Poslovanje nekretninama & & 1 & & & 1 \\
\hline Prerađivačka industrija & 10 & 10 & 4 & 3 & 27 \\
\hline Prijevoz i skladištenje & 4 & & 1 & & 5 \\
\hline Stručne, znanstv. i tehničke djel. & & 2 & & & 2 \\
\hline Trgovina na veliko i na malo & 3 & 2 & 1 & & 6 \\
\hline
\end{tabular}




\section{Nastavak tablice 3}

\begin{tabular}{|c|c|c|c|c|c|}
\hline \multicolumn{6}{|c|}{$\begin{array}{l}\text { Pitanje 14.: Konkurentska sila „Prijetnja novih sudionika“ } \\
\text { za konkurentnost mojeg poduzeće ima razinu utjecaja: }\end{array}$} \\
\hline & $\begin{array}{c}\text { Promet } \\
<\text { od } \\
10 \mathrm{mil} €\end{array}$ & $\begin{array}{c}\text { Promet } \\
<\text { od } \\
2 \text { mil } €\end{array}$ & $\begin{array}{c}\text { Promet } \\
<\text { od } \\
50 \text { mil } €\end{array}$ & $\begin{array}{c}\text { Promet } \\
>\text { od } \\
50 \text { mil } €\end{array}$ & $\Sigma$ \\
\hline 4. Niska & 9 & 1 & 6 & 7 & 23 \\
\hline Financijske djelatnosti i osiguranje & 1 & & & & 1 \\
\hline Građevinarstvo & 1 & & & 1 & 2 \\
\hline Informacije i komunikacije & & & 1 & 1 & 2 \\
\hline Ostale uslužne djelatnosti & 2 & & & & 2 \\
\hline Poljoprivreda, šumarstvo i ribarst. & & & 1 & & 1 \\
\hline Popravak motor. vozila i motocikla & 1 & & & & 1 \\
\hline Prerađivačka industrija & 3 & & 3 & 5 & 11 \\
\hline Rudarstvo i vađenje & 1 & & & & 1 \\
\hline Stručne, znanstv. i tehničke djelat. & & 1 & & & 1 \\
\hline Trgovina na veliko i na malo & & & 1 & & 1 \\
\hline 5. Potpuno niska & 2 & 1 & 2 & 3 & 8 \\
\hline Informacije i komunikacije & & & & 1 & 1 \\
\hline Prerađivačka industrija & 1 & & 1 & & 2 \\
\hline Prijevoz i skladištenje & & 1 & & & 1 \\
\hline Stručne, znanstv. i tehničke djel. & 1 & & & & 1 \\
\hline Trgovina na veliko i na malo & & & 1 & 1 & 2 \\
\hline Umjetnost, zabava i rekreacija & & & & 1 & 1 \\
\hline Ukupno & 47 & 33 & 30 & 23 & 133 \\
\hline
\end{tabular}

Izvor: Marić, K. (2019). Modeli za podizanje izvozne konkurentnosti hrvatskoga gospodarstva, doktorski rad, Sveučilište u Zadru i Sveučilište Libertas, str. 121-122.

„U tablici je prikazana razina utjecaja konkurentske sile prijetnja novih sudionika na konkurentnost 133 analizirana poduzeća. Stavovi ispitanika prikazani su na temelju analize prema Likertu, kako slijedi: 1. Iznimno visoka - 13 poduzeća, 2. Visoka - 31 poduzeće, 3. Podjednako visoka i niska - 58 poduzeća, 4. Niska - 23 poduzeća, 5. Potpuno niska - 8 poduzeća. Pivot tablica je višedimenzionalna i u istoj je prikazan utjecaj konkurentske sile „Prijetnja novih sudionika“ na konkurentnost analiziranih poduzeća u odnosu na sektore gospodarstva u kojima posluju ta poduzeća i njihov ukupni promet." (Marić, 2019, 123) 
Tablica 4 Deskriptivna statistička analiza odgovora ispitanika na anketno pitanje 14.

\begin{tabular}{|l|c|}
\hline Aritmetička sredina & 2,86 \\
\hline Median & 3 \\
\hline Mode & 3 \\
\hline Standardna devijacija & 1,01 \\
\hline Koeficijent varijabilnosti & $35,24 \%$ \\
\hline Koeficijent asimetrije & 0,05 \\
\hline Broj uzoraka & 133 \\
\hline
\end{tabular}

Izvor: Marić, K. (2019). Modeli za podizanje izvozne konkurentnosti hrvatskoga gospodarstva, doktorski rad, Sveučilište u Zadru i Sveučilište Libertas, str. 123.

„U tablici su prikazani rezultati deskriptivne statističke analize odgovora ispitanika na pitanje 14. iz ankete o razini utjecaja konkurentske sile prijetnja novih sudionika na konkurentnost 133 analizirana poduzeća. Vrijednosti aritmetičke sredine, medijana i moda ukazuju da su ispitanici u većoj mjeri davali „niže“ odgovore što ukazuje na veću zainteresiranost. To potvrđuje i koeficijent asimetrije koji iznosi 0,05. Minimalna pozitivnost koeficijenta asimetrije ukazuje da konkurentska sila prijetnja novih sudionika ima neznatan utjecaj na konkurentnost analiziranih poduzeća." (Marić, 2019, 123)

Tablica 5 Utjecaj konkurentske sile prijetnja proizvoda supstituta na konkurentnost analiziranih poduzeća iz ankete empirijskog istraživanja

\begin{tabular}{|c|c|c|c|c|c|}
\hline \multicolumn{6}{|c|}{$\begin{array}{l}\text { Pitanje 15.: Konkurentska sila „Prijetnja proizvoda supstituta“ } \\
\text { za konkurentnost mojeg poduzeće ima razinu utjecaja: }\end{array}$} \\
\hline & $\begin{array}{c}\text { Promet } \\
<\text { od } \\
10 \mathrm{mil} €\end{array}$ & $\begin{array}{c}\text { Promet } \\
<\text { od } \\
2 \text { mil } €\end{array}$ & $\begin{array}{c}\text { Promet } \\
<\text { od } \\
50 \text { mil } €\end{array}$ & $\begin{array}{c}\text { Promet } \\
>\text { od } \\
50 \mathrm{mil} €\end{array}$ & $\Sigma$ \\
\hline 1. Iznimno visoka & 5 & & 4 & 2 & 11 \\
\hline Izvan teritorijalnih organizac. i tijela & 1 & & & & 1 \\
\hline Informacije i komunikacije & 1 & & & & 1 \\
\hline Ostale uslužne djelatnosti & & & 1 & & 1 \\
\hline Prerađivačka industrija & 1 & & 1 & 2 & 4 \\
\hline Trgovina na veliko i na malo & 2 & & 2 & & 4 \\
\hline 2. Visoka & 8 & 9 & 5 & 7 & 29 \\
\hline Zdravstvena zaštita i socijalna skrb & & & 1 & & 1 \\
\hline Građevinarstvo & & & 1 & & 1 \\
\hline Informacije i komunikacije & & 2 & 2 & 1 & 5 \\
\hline Ostale uslužne djelatnosti & & 1 & & & 1 \\
\hline Poslovanje nekretninama & & 1 & & & 1 \\
\hline Prerađivačka industrija & 4 & 4 & 1 & 2 & 11 \\
\hline Prijevoz i skladištenje & 1 & & & & 1 \\
\hline Trgovina na veliko i na malo & 3 & 1 & & 4 & 8 \\
\hline
\end{tabular}




\section{Nastavak tablice 5}

\begin{tabular}{|c|c|c|c|c|c|}
\hline \multicolumn{6}{|c|}{$\begin{array}{l}\text { Pitanje 15.: Konkurentska sila „Prijetnja proizvoda supstituta“ } \\
\text { za konkurentnost mojeg poduzeće ima razinu utjecaja: }\end{array}$} \\
\hline & $\begin{array}{c}\text { Promet } \\
<\text { od } \\
10 \text { mil } €\end{array}$ & $\begin{array}{c}\text { Promet } \\
<\text { od } \\
2 \text { mil } €\end{array}$ & $\begin{array}{c}\text { Promet } \\
<\text { od } \\
50 \text { mil } €\end{array}$ & $\begin{array}{c}\text { Promet } \\
>\text { od } \\
50 \mathrm{mil} €\end{array}$ & $\Sigma$ \\
\hline 3. Podjednako visoka i niska & 14 & 12 & 6 & 5 & 37 \\
\hline Izvan teritorijalne organizac. i tijela & & 1 & & & 1 \\
\hline Financijske djelatnosti i osiguranje & 1 & 1 & & & 2 \\
\hline Građevinarstvo & 1 & 1 & & & 2 \\
\hline Informacije i komunikacije & & & & 1 & 1 \\
\hline El. energ., plin, para i klimatizacija & & & 1 & & 1 \\
\hline Ostale uslužne djelatnosti & & 1 & & & 1 \\
\hline Poljoprivreda, šumarstvo i ribarstvo & 2 & 1 & 2 & & 5 \\
\hline Prerađivačka industrija & 7 & 3 & 2 & 3 & 15 \\
\hline Prijevoz i skladištenje & 2 & & & & 2 \\
\hline Stručne, znanstv. i tehničke djelat. & & 1 & & & 1 \\
\hline Trgovina na veliko i na malo & 1 & 3 & 1 & 1 & 6 \\
\hline 4. Niska & 16 & 7 & 13 & 8 & 44 \\
\hline Zdravstvena zaštita i socijalna skrb & 1 & & & & 1 \\
\hline Građevinarstvo & 1 & & 1 & 2 & 4 \\
\hline Informacije i komunikacije & & & 2 & & 2 \\
\hline Ostale uslužne djelatnosti & 2 & & & & 2 \\
\hline Poljoprivreda, šumarstvo i ribarstvo & & & 1 & & 1 \\
\hline Popravak motor. vozila i motocikla & 1 & & & & 1 \\
\hline Poslovanje nekretninama & & 1 & & & 1 \\
\hline Prerađivačka industrija & 6 & 4 & 7 & 5 & 22 \\
\hline Prijevoz i skladištenje & 1 & 1 & 1 & & 3 \\
\hline Rudarstvo i vađenje & 1 & & & & 1 \\
\hline Stručne, znanstv. i tehničke djelat. & & 1 & & & 1 \\
\hline Trgovina na veliko i na malo & 3 & & 1 & & 4 \\
\hline Umjetnost, zabava i rekreacija & & & & 1 & 1 \\
\hline 5. Potpuno niska & 4 & 5 & 2 & 1 & 12 \\
\hline Poljoprivreda, šumarstvo i ribarstvo & & 1 & & & 1 \\
\hline Prerađivačka industrija & 3 & 3 & 2 & 1 & 9 \\
\hline Stručne, znanstv. i tehničke djelat. & 1 & 1 & & & 2 \\
\hline Ukupno & 47 & 33 & 30 & 23 & 133 \\
\hline
\end{tabular}

Izvor: Marić, K. (2019). Modeli za podizanje izvozne konkurentnosti hrvatskoga gospodarstva, doktorski rad, Sveučilište u Zadru i Sveučilište Libertas, str. 124-125. 
„U tablici je prikazana razina utjecaja konkurentske sile prijetnja proizvoda supstituta na konkurentnost 133 analizirana poduzeća. Stavovi ispitanika prikazani su na temelju analize prema Likertu, kako slijedi: 1. Iznimno visoka - 11 poduzeća, 2. Visoka - 29 poduzeća, 3. Podjednako visoka i niska - 37 poduzeća, 4. Niska - 44 poduzeća, 5. Potpuno niska - 12 poduzeća. Pivot tablica je višedimenzionalna i u istoj je prikazan utjecaj konkurentske sile prijetnja proizvoda supstituta na konkurentnost analiziranih poduzeća u odnosu na sektore gospodarstva u kojima ta poduzeća posluju i njihov ukupni promet." (Marić, 2019, str. 126)

Tablica 6 Deskriptivna statistička analiza odgovora ispitanika na anketno pitanje 15.

\begin{tabular}{|l|c|}
\hline Aritmetička sredina & 3,13 \\
\hline Median & 3 \\
\hline Mode & 4 \\
\hline Standardna devijacija & 1,11 \\
\hline Koeficijent varijabilnosti & $35,37 \%$ \\
\hline Koeficijent asimetrije & $-0,22$ \\
\hline Broj uzoraka & 133 \\
\hline
\end{tabular}

Izvor: Marić, K. (2019). Modeli za podizanje izvozne konkurentnosti hrvatskoga gospodarstva, doktorski rad, Sveučilište u Zadru i Sveučilište Libertas, str. 126.

„U tablici su prikazani rezultati deskriptivne statističke analize odgovora ispitanika na pitanje 15. iz ankete o razini utjecaja konkurentske sile prijetnja proizvoda supstituta na konkurentnost 133 analizirana poduzeća. Vrijednosti aritmetičke sredine, medijana i moda ukazuju da su ispitanici u većoj mjeri davali „više“ odgovore što ukazuje na manju zainteresiranost. To potvrđuje i koeficijent asimetrije, koji iznosi -0,22. Negativnost koeficijenta asimetrije ukazuje da konkurentska sila prijetnja proizvoda supstituta za većinu ispitanika nema utjecaj na konkurentnost analiziranih poduzeća." (Marić, 2019, 126)

Tablica 7 Utjecaj konkurentske sile pregovaračka moć dobavljača na konkurentnost analiziranih poduzeća iz ankete empirijskog istraživanja

\begin{tabular}{|c|c|c|c|c|c|}
\hline \multicolumn{6}{|c|}{$\begin{array}{l}\text { Pitanje 16.: Konkurentska sila „Pregovaračka moć dobavljača“ } \\
\text { za konkurentnost mojeg poduzeće ima razinu utjecaja: }\end{array}$} \\
\hline & $\begin{array}{c}\text { Promet } \\
<\text { od } \\
10 \mathrm{mil} €\end{array}$ & $\begin{array}{c}\text { Promet } \\
<\text { od } \\
2 \text { mil } €\end{array}$ & $\begin{array}{c}\text { Promet } \\
<\text { od } \\
50 \mathrm{mil} €\end{array}$ & $\begin{array}{c}\text { Promet } \\
>\text { od } \\
50 \text { mil } €\end{array}$ & $\Sigma$ \\
\hline 1. Iznimno visoka & 4 & 3 & 3 & 2 & 12 \\
\hline Informacije i komunikacije & & & 1 & & 1 \\
\hline Prerađivačka industrija & 1 & 3 & 1 & 1 & 6 \\
\hline Trgovina na veliko i na malo & 3 & & 1 & 1 & 5 \\
\hline
\end{tabular}




\section{Nastavak tablice 7}

\begin{tabular}{|c|c|c|c|c|c|}
\hline \multicolumn{6}{|c|}{$\begin{array}{l}\text { Pitanje 16.: Konkurentska sila „Pregovaračka moć dobavljača“ } \\
\text { za konkurentnost mojeg poduzeće ima razinu utjecaja: }\end{array}$} \\
\hline & $\begin{array}{c}\text { Promet } \\
<\text { od } \\
10 \text { mil } €\end{array}$ & $\begin{array}{c}\text { Promet } \\
<\text { od } \\
2 \mathrm{mil} €\end{array}$ & $\begin{array}{c}\text { Promet } \\
<\text { od } \\
50 \text { mil } €\end{array}$ & $\begin{array}{c}\text { Promet } \\
>\text { od } \\
50 \text { mil } €\end{array}$ & $\Sigma$ \\
\hline 2. Visoka & 9 & 10 & 9 & 7 & 35 \\
\hline Izvanteritorijalne organizac. i tijela & 1 & & & & 1 \\
\hline Građevinarstvo & 2 & 1 & 1 & & 4 \\
\hline Informacije i komunikacije & & & 2 & 2 & 4 \\
\hline El. energ., plin, para i klimatizacija & & & 1 & & 1 \\
\hline Ostale uslužne djelatnosti & & & 1 & & 1 \\
\hline Poljoprivreda, šumarstvo i ribarstvo & & 2 & & & 2 \\
\hline Poslovanje nekretninama & & 1 & & & 1 \\
\hline Prerađivačka industrija & 4 & 2 & 3 & 3 & 12 \\
\hline Stručne, znanstv. i tehničke djelat. & & 1 & & & 1 \\
\hline Trgovina na veliko i na malo & 2 & 3 & 1 & 1 & 7 \\
\hline Umjetnost, zabava i rekreacija & & & & 1 & 1 \\
\hline 3. Podjednako visoka i niska & 15 & 10 & 13 & 9 & 47 \\
\hline Izvanteritorijalne organizac. i tijela & & 1 & & & 1 \\
\hline Zdravstvena zaštita i socijalna skrb & & & 1 & & 1 \\
\hline Financijske djelatnosti i osiguranje & 1 & 1 & & & 2 \\
\hline Građevinarstvo & & & & 2 & 2 \\
\hline Informacije i komunikacije & 1 & & 1 & & 2 \\
\hline Poljoprivreda, šumarstvo i ribarstvo & 2 & & 3 & & 5 \\
\hline Poslovanje nekretninama & & 1 & & & 1 \\
\hline Prerađivačka industrija & 8 & 6 & 6 & 5 & 25 \\
\hline Prijevoz i skladištenje & 1 & & 1 & & 2 \\
\hline Trgovina na veliko i na malo & 2 & 1 & 1 & 2 & 6 \\
\hline 4. Niska & 16 & 10 & 3 & 5 & 34 \\
\hline Zdravstvena zaštita i socijalna skrb & 1 & & & & 1 \\
\hline Informacije i komunikacije & & 2 & & & 2 \\
\hline Ostale uslužne djelatnosti & 2 & 2 & & & 4 \\
\hline Popravak motor. vozila i motocikla & 1 & & & & 1 \\
\hline Prerađivačka industrija & 7 & 3 & 2 & 4 & 16 \\
\hline Prijevoz i skladištenje & 2 & 1 & & & 3 \\
\hline Rudarstvo i vađenje & 1 & & & & 1 \\
\hline Stručne, znanstv. i tehničke djelat. & & 2 & & & 2 \\
\hline Trgovina na veliko i na malo & 2 & & 1 & 1 & 4 \\
\hline
\end{tabular}




\section{Nastavak tablice 7}

\begin{tabular}{|c|c|c|c|c|c|}
\hline \multicolumn{6}{|c|}{$\begin{array}{l}\text { Pitanje 16.: Konkurentska sila „Pregovaračka moć dobavljača“ } \\
\text { za konkurentnost mojeg poduzeće ima razinu utjecaja: }\end{array}$} \\
\hline & $\begin{array}{l}\text { Promet } \\
<\text { od } \\
10 \mathrm{mil} €\end{array}$ & $\begin{array}{l}\text { Promet } \\
<\text { od } \\
2 \text { mil } €\end{array}$ & $\begin{array}{l}\text { Promet } \\
<\text { od } \\
50 \mathrm{mil} €\end{array}$ & $\begin{array}{l}\text { Promet } \\
>\text { od } \\
50 \mathrm{mil} €\end{array}$ & $\Sigma$ \\
\hline 5. Potpuno niska & 3 & & 2 & & 5 \\
\hline Građevinarstvo & & & 1 & & 1 \\
\hline Prerađivačka industrija & 1 & & 1 & & 2 \\
\hline Prijevoz i skladištenje & 1 & & & & 1 \\
\hline Stručne, znanstv. i tehničke djelat. & 1 & & & & 1 \\
\hline Ukupno & 47 & 33 & 30 & 23 & 133 \\
\hline
\end{tabular}

Izvor: Marić, K. (2019). Modeli za podizanje izvozne konkurentnosti hrvatskoga gospodarstva, doktorski rad, Sveučilište u Zadru i Sveučilište Libertas, str. 127-128.

„U tablici je prikazana razina utjecaja konkurentske sile pregovaračka moć dobavljača na konkurentnost 133 analizirana poduzeća. Stavovi ispitanika prikazani su na temelju analize prema Likertu, kako slijedi: 1. Iznimno visoka - 12 poduzeća, 2. Visoka - 35 poduzeća, 3. Podjednako visoka i niska - 47 poduzeća, 4. Niska - 34 poduzeća, 5. Potpuno niska - 5 poduzeća. Pivot tablica je višedimenzionalna i u istoj je prikazan utjecaj konkurentske sile pregovaračka moć dobavljača na konkurentnost analiziranih poduzeća u odnosu na sektore gospodarstva u kojima posluju ta poduzeća i njihov ukupni promet." (Marić, 2019, 128-129).

Tablica 8 Deskriptivna statistička analiza odgovora ispitanika na anketno pitanje 16.

\begin{tabular}{|l|c|}
\hline Aritmetička sredina & 2,89 \\
\hline Median & 3 \\
\hline Mode & 3 \\
\hline Standardna devijacija & 1,01 \\
\hline Koeficijent varijabilnosti & $34,93 \%$ \\
\hline Koeficijent asimetrije & $-0,08$ \\
\hline Broj uzoraka & 133 \\
\hline
\end{tabular}

Izvor: Marić, K. (2019). Modeli za podizanje izvozne konkurentnosti hrvatskoga gospodarstva, doktorski rad, Sveučilište u Zadru i Sveučilište Libertas, str. 129.

„U tablici su prikazani rezultati deskriptivne statističke analize odgovora ispitanika na pitanje 16. iz ankete o razini utjecaja konkurentske sile pregovaračka moć dobavljača na konkurentnost 133 analizirana poduzeća. Vrijednosti aritmetičke sredine, medijana i moda ukazuju da su ispitanici u većoj mjeri davali „više“ odgovore što ukazuje na manju zainteresiranost. To potvrđuje i koeficijent asimetrije koji iznosi -0,08. Negativnost koeficijenta asimetrije ukazuje da konkurentska sila pregovaračka moć dobavljača za većinu ispitanika nema utjecaj na konkurentnost analiziranih poduzeća." (Marić, 2019, 129) 
Tablica 9 Utjecaj konkurentske sile pregovaračka moć kupaca na konkurentnost analiziranih poduzeća iz ankete empirijskog istraživanja

\begin{tabular}{|c|c|c|c|c|c|}
\hline \multicolumn{6}{|c|}{$\begin{array}{l}\text { Pitanje 17.: Konkurentska sila „Pregovaračka moć kupaca“ } \\
\text { za konkurentnost mojeg poduzeće ima razinu utjecaja: }\end{array}$} \\
\hline & $\begin{array}{c}\text { Promet } \\
<\text { od } \\
10 \text { mil } €\end{array}$ & $\begin{array}{c}\text { Promet } \\
<\text { od } \\
2 \mathrm{mil} €\end{array}$ & $\begin{array}{c}\text { Promet } \\
<\text { od } \\
50 \text { mil } €\end{array}$ & $\begin{array}{c}\text { Promet } \\
>\text { od } \\
50 \mathrm{mil} €\end{array}$ & $\Sigma$ \\
\hline 1. Iznimno visoka & 8 & 4 & 4 & 3 & 19 \\
\hline Informacije i komunikacije & & 1 & 1 & 1 & 3 \\
\hline Prerađivačka industrija & 6 & 3 & 2 & 1 & 12 \\
\hline Trgovina na veliko i na malo & 2 & & 1 & 1 & 4 \\
\hline 2. Visoka & 13 & 11 & 11 & 10 & 45 \\
\hline Izvanteritorijalne organizac. i tijela & 1 & & & & 1 \\
\hline Zdravstv. zaštita i socijalna skrb & 1 & & & & 1 \\
\hline Financijske djelatnosti i osiguranje & 1 & & & & 1 \\
\hline Građevinarstvo & & 1 & 2 & 1 & 4 \\
\hline Informacije i komunikacije & 1 & 1 & 2 & & 4 \\
\hline El. energ., plin, para i klimatizacija & & & 1 & & 1 \\
\hline Ostale uslužne djelatnosti & & 1 & & & 1 \\
\hline Poljoprivreda, šumarstvo i ribarst. & & 1 & & & 1 \\
\hline Poslovanje nekretninama & & 2 & & & 2 \\
\hline Prerađivačka industrija & 4 & 5 & 6 & 6 & 21 \\
\hline Prijevoz i skladištenje & 1 & & & & 1 \\
\hline Trgovina na veliko i na malo & 4 & & & 3 & 7 \\
\hline 3. Podjednako visoka i niska & 17 & 16 & 9 & 5 & 47 \\
\hline Izvanteritorijalne organizac. i tijela & & 1 & & & 1 \\
\hline Financijske djelatnosti i osiguranje & & 1 & & & 1 \\
\hline Građevinarstvo & 2 & & & 1 & 3 \\
\hline Informacije i komunikacije & & & 1 & & 1 \\
\hline Ostale uslužne djelatnosti & & 1 & 1 & & 2 \\
\hline Poljoprivreda, šumarstvo i ribarst. & 2 & 1 & 2 & & 5 \\
\hline Popravak motor. vozila i motocikla & 1 & & & & 1 \\
\hline Prerađivačka industrija & 7 & 6 & 2 & 2 & 17 \\
\hline Prijevoz i skladištenje & 2 & & 1 & & 3 \\
\hline Stručne, znanstv. i tehničke djelat. & & 2 & & & 2 \\
\hline Trgovina na veliko i na malo & 3 & 4 & 2 & 1 & 10 \\
\hline Umjetnost, zabava i rekreacija & & & & 1 & 1 \\
\hline
\end{tabular}




\section{Nastavak tablice 9}

\begin{tabular}{|c|c|c|c|c|c|}
\hline \multicolumn{6}{|c|}{$\begin{array}{l}\text { Pitanje 17.: Konkurentska sila „Pregovaračka moć kupaca“ } \\
\text { za konkurentnost mojeg poduzeće ima razinu utjecaja: }\end{array}$} \\
\hline & $\begin{array}{c}\text { Promet } \\
<\text { od } \\
10 \mathrm{mil} €\end{array}$ & $\begin{array}{c}\text { Promet } \\
<\text { od } \\
2 \text { mil } €\end{array}$ & $\begin{array}{c}\text { Promet } \\
<\text { od } \\
50 \mathrm{mil} €\end{array}$ & $\begin{array}{c}\text { Promet } \\
>\text { od } \\
50 \mathrm{mil} €\end{array}$ & $\Sigma$ \\
\hline 4. Niska & 7 & 2 & 5 & 4 & 18 \\
\hline Zdravstv. zaštita i socijalna skrb & & & 1 & & 1 \\
\hline Informacije i komunikacije & & & & 1 & 1 \\
\hline Ostale uslužne djelatnosti & 2 & & & & 2 \\
\hline Poljoprivreda, šumarstvo i ribarst. & & & 1 & & 1 \\
\hline Prerađivačka industrija & 3 & & 2 & 3 & 8 \\
\hline Prijevoz i skladištenje & 1 & 1 & & & 2 \\
\hline Rudarstvo i vađenje & 1 & & & & 1 \\
\hline Stručne, znanstv. i tehničke djelat. & & 1 & & & 1 \\
\hline Trgovina na veliko i na malo & & & 1 & & 1 \\
\hline 5. Potpuno niska & 2 & & 1 & 1 & 4 \\
\hline Prerađivačka industrija & 1 & & 1 & 1 & 3 \\
\hline Stručne, znanst. i tehničke djelat. & 1 & & & & 1 \\
\hline Ukupno & 47 & 33 & 30 & 23 & 133 \\
\hline
\end{tabular}

Izvor: Marić, K. (2019). Modeli za podizanje izvozne konkurentnosti hrvatskoga gospodarstva, doktorski rad, Sveučilište u Zadru i Sveučilište Libertas, str. 130-131.

„U tablici je prikazana razina utjecaja konkurentske sile pregovaračka moć kupaca na konkurentnost 133 analizirana poduzeća. Stavovi ispitanika prikazani su na temelju analize prema Likertu, kako slijedi: 1. Iznimno visoka - 19 poduzeća, 2. Visoka - 45 poduzeća, 3. Podjednako visoka i niska - 47 poduzeća, 4. Niska - 18 poduzeća, 5. Potpuno niska - 4 poduzeća. Pivot je tablica višedimenzionalna i u istoj je prikazan utjecaj konkurentske sile pregovaračka moć kupaca na konkurentnost analiziranih poduzeća u odnosu na sektore gospodarstva u kojima posluju ta poduzeća i njihov ukupni promet." (Marić, 2019, 131-132)

Tablica 10 Deskriptivna statistička analiza odgovora ispitanika na anketno pitanje 17.

\begin{tabular}{|l|c|}
\hline Aritmetička sredina & 2,57 \\
\hline Median & 3 \\
\hline Mode & 3 \\
\hline Standardna devijacija & 0,99 \\
\hline Koeficijent varijabilnosti & $38,53 \%$ \\
\hline Koeficijent asimetrije & 0,25 \\
\hline Broj uzoraka & 133 \\
\hline
\end{tabular}

Izvor: Marić, K. (2019). Modeli za podizanje izvozne konkurentnosti hrvatskoga gospodarstva, doktorski rad, Sveučilište u Zadru i Sveučilište Libertas, str. 132. 
„U tablici su prikazani rezultati deskriptivne statističke analize odgovora ispitanika na pitanje 17. iz ankete o razini utjecaja konkurentske sile pregovaračka moć kupaca na konkurentnost 133 analizirana poduzeća. Vrijednosti aritmetičke sredine, medijana i moda ukazuju da su ispitanici u većoj mjeri davali „niže“ odgovore što ukazuje na veću zainteresiranost. To potvrđuje i koeficijent asimetrije, koji iznosi 0,25. Slaba pozitivnost koeficijenta asimetrije ukazuje da konkurentska sila pregovaračka moć kupaca ima slab utjecaj na konkurentnost analiziranih poduzeća." (Marić, 2019, 132)

Tablica 11 Utjecaj konkurentske sile rivalitet među postojećim poduzećima na konkurentnost analiziranih poduzeće iz anketnog upitnika empirijskog istraživanja

\begin{tabular}{|c|c|c|c|c|c|}
\hline \multicolumn{6}{|c|}{$\begin{array}{l}\text { Pitanje 18.: Konkurentska sila „Rivalitet među postojećim poduzećima“ za konkurentnost mojeg } \\
\text { poduzeće ima razinu utjecaja: }\end{array}$} \\
\hline & $\begin{array}{c}\text { Promet } \\
<\text { od } \\
10 \mathrm{mil} €\end{array}$ & $\begin{array}{c}\text { Promet } \\
<\text { od } \\
2 \text { mil } €\end{array}$ & $\begin{array}{l}\text { Promet } \\
<\text { od } \\
50 \mathrm{mil} €\end{array}$ & $\begin{array}{c}\text { Promet } \\
>\text { od } \\
50 \mathrm{mil} €\end{array}$ & $\Sigma$ \\
\hline 1. Iznimno visoka & 9 & 5 & 5 & 3 & 22 \\
\hline Zdravstvena zaštite i socijalna skrb & 1 & & & & 1 \\
\hline Informacije i komunikacije & 1 & 1 & & 2 & 4 \\
\hline Poljoprivreda, šumarstvo i ribarstvo & & 1 & & & 1 \\
\hline Poslovanje nekretninama & & 1 & & & 1 \\
\hline Prerađivačka industrija & 3 & 1 & 4 & 1 & 9 \\
\hline Trgovina na veliko i na malo & 4 & 1 & 1 & & 6 \\
\hline 2. Visoka & 10 & 9 & 11 & 8 & 38 \\
\hline Izvanteritorijalne organizac. i tijela & 1 & & & & 1 \\
\hline Zdravstvena zaštita i socijalna skrb & & & 1 & & 1 \\
\hline Građevinarstvo & & & 1 & & 1 \\
\hline Informacije i komunikacije & & & 2 & & 2 \\
\hline El. energ., plin, para i klimatizacija & & & 1 & & 1 \\
\hline Ostale uslužne djelatnosti & & 2 & 1 & & 3 \\
\hline Poljoprivreda, šumarstvo i ribarstvo & 1 & 1 & & & 2 \\
\hline Poslovanje nekretninama & & 1 & & & 1 \\
\hline Prerađivačka industrija & 4 & 4 & 4 & 5 & 17 \\
\hline Prijevoz i skladištenje & 1 & & 1 & & 2 \\
\hline Trgovina na veliko i na malo & 3 & 1 & & 3 & 7 \\
\hline 3. Podjednako visoka i niska & 19 & 12 & 11 & 6 & 48 \\
\hline Izvanteritorijalne organizac. i tijela & & 1 & & & 1 \\
\hline Financijske djelatnosti i osiguranje & 1 & 1 & & & 2 \\
\hline Građevinarstvo & & & & 1 & 1 \\
\hline Informacije i komunikacije & & 1 & 2 & & 3 \\
\hline Ostale uslužne djelatnosti & 1 & & & & 1 \\
\hline
\end{tabular}




\section{Nastavak tablice 11}

\begin{tabular}{|c|c|c|c|c|c|}
\hline \multicolumn{6}{|c|}{$\begin{array}{l}\text { Pitanje 18.: Konkurentska sila „Rivalitet među postojećim poduzećima“ za konkurentnost mojeg } \\
\text { poduzeće ima razinu utjecaja: }\end{array}$} \\
\hline & $\begin{array}{c}\text { Promet } \\
<\text { od } \\
10 \mathrm{mil} €\end{array}$ & $\begin{array}{c}\text { Promet } \\
<\text { od } \\
2 \text { mil } €\end{array}$ & $\begin{array}{c}\text { Promet } \\
<\text { od } \\
50 \mathrm{mil} €\end{array}$ & $\begin{array}{c}\text { Promet } \\
>\text { od } \\
50 \mathrm{mil} €\end{array}$ & $\Sigma$ \\
\hline Poljoprivreda, šumarstvo i ribarstvo & 1 & & 3 & & 4 \\
\hline Prerađivačka industrija & 12 & 5 & 4 & 4 & 25 \\
\hline Prijevoz i skladištenje & 2 & 1 & & & 3 \\
\hline Stručne, znanstv. i tehničke djelat. & & 2 & & & 2 \\
\hline Trgovina na veliko i na malo & 2 & 1 & 2 & & 5 \\
\hline Umjetnost, zabava i rekreacija & & & & 1 & 1 \\
\hline 4. Niska & 7 & 6 & 3 & 5 & 21 \\
\hline Građevinarstvo & 1 & 1 & 1 & 1 & 4 \\
\hline Ostale uslužne djelatnosti & 1 & & & & 1 \\
\hline Popravak motor. vozila i motocikla & 1 & & & & 1 \\
\hline Prerađivačka industrija & 2 & 4 & 1 & 3 & 10 \\
\hline Prijevoz i skladištenje & 1 & & & & 1 \\
\hline Rudarstvo i vađenje & 1 & & & & 1 \\
\hline Stručne, znanstv. i tehničke djelat. & & 1 & & & 1 \\
\hline Trgovina na veliko i na malo & & & 1 & 1 & 2 \\
\hline 5. Potpuno niska & 2 & 1 & & 1 & 4 \\
\hline Građevinarstvo & 1 & & & & 1 \\
\hline Stručne, znanstv. i tehničke djelat. & 1 & & & & 1 \\
\hline Trgovina na veliko i na malo & & 1 & & 1 & 2 \\
\hline Ukupno & 47 & 33 & 30 & 23 & 133 \\
\hline
\end{tabular}

Izvor: Marić, K. (2019) Modeli za podizanje izvozne konkurentnosti hrvatskoga gospodarstva, doktorski rad, Sveučilište u Zadru i Sveučilište Libertas, str. 133-134.

„U tablici je prikazana razina utjecaja konkurentske sile rivalitet među postojećim poduzećima na konkurentnost 133 analizirana poduzeća. Stavovi ispitanika prikazani su na temelju analize prema Likertu, kako slijedi: 1. Iznimno visoka - 22 poduzeća, 2. Visoka - 38 poduzeća, 3. Podjednako visoka i niska - 48 poduzeća, 4. Niska - 21 poduzeće, 5. Potpuno niska - 4 poduzeća. Pivot tablica je višedimenzionalna i u istoj je prikazan utjecaj konkurentske sile rivalitet među postojećim poduzećima na konkurentnost analiziranih poduzeća u odnosu na sektore gospodarstva u kojima posluju ta poduzeća i njihov ukupni promet." (Marić, 2019, 135) 
Tablica 12 Deskriptivna statistička analiza odgovora ispitanikana anketno pitanje 18.

\begin{tabular}{|l|c|}
\hline Aritmetička sredina & 2,60 \\
\hline Median & 3 \\
\hline Mode & 3 \\
\hline Standardna devijacija & 1,03 \\
\hline Koeficijent varijabilnosti & $39,70 \%$ \\
\hline Koeficijent asimetrije & 0,12 \\
\hline Broj uzoraka & 133 \\
\hline
\end{tabular}

Izvor: Marić, K. (2019). Modeli za podizanje izvozne konkurentnosti hrvatskoga gospodarstva, doktorski rad, Sveučilište u Zadru i Sveučilište Libertas, str. 135.

„U tablici su prikazani rezultati deskriptivne statističke analize odgovora ispitanika na pitanje 18. iz ankete o razini utjecaja konkurentske sile rivalitet među postojećim poduzećima na konkurentnost 133 analizirana poduzeća. Vrijednosti aritmetičke sredine, medijana i moda ukazuju da su ispitanici u većoj mjeri davali „niže“ odgovore što ukazuje na veću zainteresiranost. To potvrđuje i koeficijent asimetrije koji iznosi 0,12. Slaba pozitivnost koeficijenta asimetrije ukazuje da konkurentska sila rivalitet među postojećim poduzećima ima slab utjecaj na konkurentnost analiziranih poduzeća." (Marić, 2019, 135)

Tablica 13 Zainteresiranost poduzeća iz ankete empirijskog istraživanja za ulaganje vlastitih resursa u podizanje svoje izvozne konkurentnosti

\begin{tabular}{|c|c|c|c|c|c|}
\hline & $\begin{array}{c}\text { Promet } \\
<\text { od } \\
10 \text { mil } €\end{array}$ & $\begin{array}{c}\text { Promet } \\
<\text { od } \\
2 \text { mil } €\end{array}$ & $\begin{array}{c}\text { Promet } \\
<\text { od } \\
50 \text { mil } €\end{array}$ & $\begin{array}{c}\text { Promet } \\
>\text { od } \\
50 \mathrm{mil} €\end{array}$ & $\Sigma$ \\
\hline 1. Iznimno zainteresirano & 17 & 4 & 7 & 10 & 38 \\
\hline Izvanteritorijalne organizac. i tijela & 1 & & & & 1 \\
\hline Građevinarstvo & 1 & & 1 & 1 & 3 \\
\hline Informacije i komunikacije & 1 & & & & 1 \\
\hline Poljoprivreda, šumarstvo i ribarstvo & & 1 & & & 1 \\
\hline Popravak motornih vozila & 1 & & & & 1 \\
\hline Prerađivačka industrija & 9 & 3 & 4 & 7 & 23 \\
\hline Prijevoz i skladištenje & 1 & & & & 1 \\
\hline Trgovina na veliko i na malo & 3 & & 2 & 2 & 7 \\
\hline 2. Zainteresirano & 11 & 15 & 14 & 12 & 52 \\
\hline Građevinarstvo & & & & 1 & 1 \\
\hline Informacije i komunikacije & & 1 & 3 & 1 & 5 \\
\hline Opskrba el. energ., plinom, parom & & & 1 & & 1 \\
\hline Ostale uslužne djelatnosti & & & 1 & & 1 \\
\hline
\end{tabular}




\section{Nastavak tablice 13}

Pitanje 19.: S ciljem podizanja izvozne konkurentnosti poduzeće je zainteresirano ulaganjem vlastitih resursa promijeniti u svoju korist konkurentske sile koje ga čine nedovoljno konkurentnima:

\begin{tabular}{|c|c|c|c|c|c|}
\hline & $\begin{array}{c}\text { Promet } \\
<\text { od } \\
10 \text { mil } €\end{array}$ & $\begin{array}{c}\text { Promet } \\
<\text { od } \\
2 \text { mil } €\end{array}$ & $\begin{array}{c}\text { Promet } \\
<\text { od } \\
50 \text { mil } €\end{array}$ & $\begin{array}{c}\text { Promet } \\
>\text { od } \\
50 \text { mil } €\end{array}$ & $\Sigma$ \\
\hline Poljoprivreda, šumarstvo i ribarstvo & 1 & 1 & 1 & & 3 \\
\hline Poslovanje nekretninama & & 2 & & & 2 \\
\hline Prerađivačka industrija & 6 & 7 & 6 & 6 & 25 \\
\hline Prijevoz i skladištenje & & & 1 & & 1 \\
\hline Rudarstvo i vađenje & 1 & & & & 1 \\
\hline Stručne, znanstv. i tehničke djelat. & & 1 & & & 1 \\
\hline Trgovina na veliko i na malo & 3 & 3 & 1 & 3 & 10 \\
\hline Umjetnost, zabava i rekreacija & & & & 1 & 1 \\
\hline $\begin{array}{l}\text { 3. Podjednako zainteresirano i } \\
\text { nezainteresiran }\end{array}$ & 13 & 12 & 8 & 1 & 34 \\
\hline Izvanteritorijalne organizac. i tijela & & 1 & & & 1 \\
\hline Zdravstvena zaštita i socijalna skrb & 1 & & 1 & & 2 \\
\hline Financijske djelatnosti i osiguranje & & 1 & & & 1 \\
\hline Građevinarstvo & 1 & 1 & 1 & & 3 \\
\hline Informacije i komunikacije & & 1 & 1 & 1 & 3 \\
\hline Ostale uslužne djelatnosti & & 2 & & & 2 \\
\hline Poljoprivreda, šumarstvo i ribarstvo & 1 & & 2 & & 3 \\
\hline Prerađivačka industrija & 4 & 4 & 2 & & 10 \\
\hline Prijevoz i skladištenje & 2 & 1 & & & 3 \\
\hline Stručne, znanstv. i tehničke djelat. & 1 & & & & 1 \\
\hline Trgovina na veliko i na malo & 3 & 1 & 1 & & 5 \\
\hline 4. Nezainteresirano & 5 & 2 & 1 & & 8 \\
\hline Ostale uslužne djelatnosti & 2 & & & & 2 \\
\hline Prerađivačka industrija & 2 & & 1 & & 3 \\
\hline Prijevoz i skladištenje & 1 & & & & 1 \\
\hline Stručne, znanstv. i tehničke djelat. & & 2 & & & 2 \\
\hline 5. Potpuno nezainteresirano & 1 & & & & 1 \\
\hline Financijske djelatnosti i osiguranje & 1 & & & & 1 \\
\hline Ukupno & 47 & 33 & 30 & 23 & 133 \\
\hline
\end{tabular}

Izvor: Marić, K. (2019). Modeli za podizanje izvozne konkurentnosti hrvatskoga gospodarstva, doktorski rad, Sveučilište u Zadru i Sveučilište Libertas, str. 136-137.

„Na uzorku od 133 analizirana poduzeća u tablici je prikazana razina zainteresiranosti poduzeća za ulaganje vlastitih resursa u podizanje svoje konkurentnosti kako bi promije- 
nila u svoju korist one konkurentske sile koja ih čini nedovoljno konkurentnima. Stavovi ispitanika prikazani su na temelju analize prema Likertu, kako slijedi: 1. Iznimno zainteresirano - 38 poduzeća, 2. Zainteresirano - 52 poduzeća, 3. Podjednako zainteresirano i nezainteresirano - 34 poduzeća, 4 . Nezainteresirano - 8 poduzeća, 5. Potpuno nezainteresirano - 1 poduzeće. Pivot tablica je višedimenzionalna i u istoj je prikazana razina zainteresiranosti poduzeća da vlastitim resursima mijenjaju u svoju korist one konkurentske sile koje ih čine nedovoljno konkurentnima u odnosu na sektore gospodarstva u kojima posluju i njihov ukupni promet." (Marić, 2019, 137-138)

Tablica 14 Deskriptivna statistička analiza odgovora ispitanika na anketno pitanje 19.

\begin{tabular}{|l|c|}
\hline Aritmetička sredina & 2,11 \\
\hline Median & 2 \\
\hline Mode & 2 \\
\hline Standardna devijacija & 0,91 \\
\hline Koeficijent varijabilnosti & $43,30 \%$ \\
\hline Koeficijent asimetrije & 0,49 \\
\hline Broj uzoraka & 133 \\
\hline
\end{tabular}

Izvor: Marić, K. (2019). Modeli za podizanje izvozne konkurentnosti hrvatskoga gospodarstva, doktorski rad, Sveučilište u Zadru i Sveučilište Libertas, str. 138.

„U tablici su prikazani rezultati deskriptivne statističke analize odgovora ispitanika na pitanje 19. iz ankete o razini zainteresiranosti poduzeća za ulaganje vlastitih resursa u podizanje svoje konkurentnosti. Analizirana su 133 poduzeća. Vrijednosti aritmetičke sredine, medijana i moda ukazuju da su ispitanici u većoj mjeri davali „niže“ odgovore što ukazuje na veću zainteresiranost. To potvrđuje i srednje jak koeficijent asimetrije koji iznosi 0,49. Srednje jaka pozitivnost koeficijenta asimetrije ukazuje da su poduzeća srednje jako spremna ulagati vlastite resurse u podizanje vlastite konkurentnosti kako bi u svoju korist promijenile one konkurentske sile koje ih u ovom trenutku čine nedovoljno konkurentnima." (Marić, 2019, 138)

\section{RANGIRANJE KONKURENTSKIH SILA ZA PODIZANJE KONKURENTNOSTI HRVATSKIH IZVOZNIKA}

Na temelju odgovora ispitanika iz ankete provedena je analiza važnosti utjecaja i rangiranje pet Porterovih konkurentskih sila statističkom analizom varijanci. Rangiranje prikazuje važnost svake pojedine Porterove sile na podizanje konkurentnosti hrvatskih izvoznih poduzeća.Predmetna analiza pokazala je da najvažniju silu za podizanje konkurentnosti hrvatskih izvoznih poduzeća predstavlja „Pregovaračka moć kupaca“.

Strateška je nakana poduzeća usmjeriti preferencije kupaca prema vlastitom asortimanu proizvoda i usluga te je stoga važno razumjeti strukturu potreba i želja kupaca. Nužno je stvoriti dodatne vrijednosti za kupce koje oni vide kao posebno važne sa stajališta povećanja svoje djelotvornosti i boljeg zadovoljavanja potreba (Tipurić i suradnici, 1999, 20). 
Tablica 15 Analiza varijanci pet konkurentskih sila

\begin{tabular}{|c|c|c|c|c|c|c|}
\hline \multicolumn{3}{|c|}{ Konkurentske sile } & Ukupno & Zbroj & Prosjek & Varijance \\
\hline \multicolumn{3}{|c|}{ Konkurentska sila „Prijetnja novih sudionika“ } & 133 & 381 & 2,864662 & 1,026999 \\
\hline \multicolumn{3}{|c|}{ Konkurentska sila „Prijetnja proizvoda supstituta“ } & 133 & 416 & 3,12782 & 1,233538 \\
\hline \multicolumn{3}{|c|}{ Konkurentska sila „Pregovaračka moć dobavljača“ } & 133 & 384 & 2,887218 & 1,025063 \\
\hline \multicolumn{3}{|c|}{ Konkurentska sila „Pregovaračka moć kupaca“ } & 133 & 342 & 2,571429 & 0,989177 \\
\hline \multicolumn{3}{|c|}{$\begin{array}{l}\text { Konkurentska sila „Rivalitet među postojećim } \\
\text { poduzećima“ }\end{array}$} & 133 & 346 & 2,601504 & 1,074846 \\
\hline Izvor varijanci & SS & df & MS & $\mathbf{F}$ & P-value & F crit \\
\hline Između grupa & 27,97593985 & 4 & 6,993985 & 6,536894 & 0,0000 & 2,38543 \\
\hline Unutar grupa & 706,1503759 & 660 & 1,069925 & & & \\
\hline Ukupno & 734,1263158 & 664 & & & & \\
\hline
\end{tabular}

Izvor: Marić, K. (2019). Modeli za podizanje izvozne konkurentnosti hrvatskoga gospodarstva, doktorski rad, Sveučilište u Zadru i Sveučilište Libertas, str. 217.

U tablici su prikazane statistički značajne razlike $(p<0,01)$ utjecaja pet analiziranih Porterovih konkurentskih sila na podizanje konkurentnosti hrvatska izvozna poduzeća.

Tablica 16 Rang utjecaja pet konkurentskih sila

\begin{tabular}{|l|c|}
\hline Rang utjecaja & Aritmetička sredina \\
\hline „Pregovaračka moć kupaca“ & $\mathbf{2 , 5 7}$ \\
\hline „Rivalitet među postojećim poduzećima“ & $\mathbf{2 , 6 0}$ \\
\hline „Prijetnja novih sudionika“ & 2,86 \\
\hline „Pregovaračka moć dobavljača“ & 2,89 \\
\hline „Prijetnja proizvoda supstituta“ & 3,13 \\
\hline
\end{tabular}

Izvor: Marić, K. (2019). Modeli za podizanje izvozne konkurentnosti hrvatskoga gospodarstva, doktorski rad, Sveučilište u Zadru i Sveučilište Libertas, str. 218.

\section{Grafikon 2. Rang utjecaja pet konkurentskih sila}

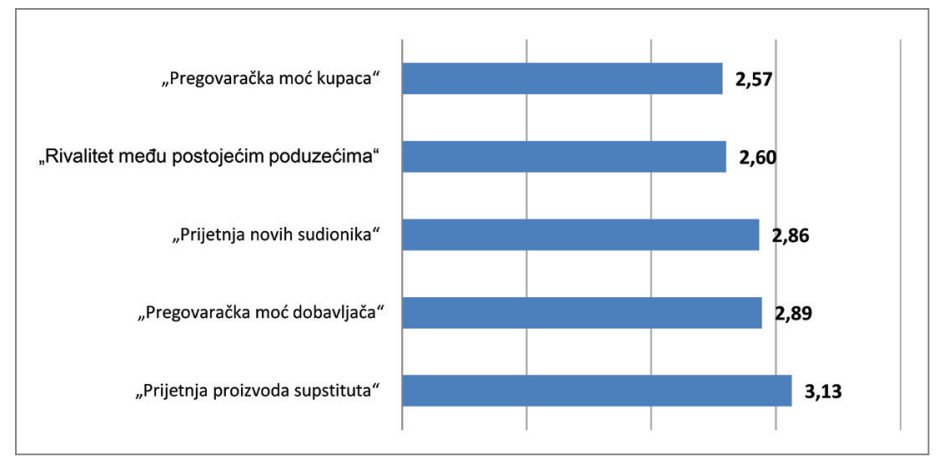

Izvor: Marić, K. (2019). Modeli za podizanje izvozne konkurentnosti hrvatskoga gospodarstva, doktorski rad, Sveučilište u Zadru i Sveučilište Libertas, str. 218. 
U tablici i na grafikonu prikazan je rang utjecaja pet Porterovih sila na konkurentnost hrvatskih izvoznih poduzeća. Iz predstavljenih rezultata vidi se da najvažniji utjecaj na podizanje konkurentnost hrvatskih izvoznika imaju konkurentske sile pregovaračka moć kupaca i rivalitet među postojećim poduzećima.

\section{ZAKLJUČAK}

Na temelju rezultata istraživanja i provedene statističke analize potvrđeno je da su hrvatski izvoznici spremni podizati svoju konkurentnost vlastitim resursima. Također, rezultati su otkrili da najznačajniji utjecaj na podizanje konkurentnosti hrvatskih izvoznika imaju konkurentske sile pregovaračka moć kupaca i rivalitet među postojećim poduzećima, a iste su opisane u drugom poglavlju ovoga rada - Porterov model pet konkurentskih sila. S druge strane, hipoteze ovoga rada potvrđene su na temelju rezultata prikazanih u istraživačkom poglavlju - Istraživanje o važnosti pet Porterovih sila za konkurentnost hrvatskih izvoznih poduzeća, u tablicama kako slijedi:

Sukladno rezultatima statističke analize prikazanima u tablici 17., nedvojbeno je potvrđena hipoteza H1: Hrvatski su izvoznici spremni ulaganjem vlastitih resursa podizati konkurentnost kako bi promijenili u svoju korist one konkurentske sile koje ih čine nedovoljno konkurentnima. Sukladno rezultatima statističke analize prikazanima u tablici 13., nedvojbeno je potvrđena hipoteza H2: Promjenom konkurentske sile pregovaračka moć kupaca u svoju korist, hrvatski izvoznici omogućuju podizanje konkurentnosti svojih poduzeća. Sukladno rezultatima statističke analize prikazanima u tablici 15., nedvojbeno je potvrđena hipoteza H3: Promjenom konkurentske sile rivalitet među postojećim poduzećima u svoju korist, hrvatski izvoznici omogućuju podizanje konkurentnosti svojih poduzeća. Sve hipoteze ovog rada nedvojbeno su dokazane, shodno čemu se može zaključiti da primjenom rezultata istraživanja ovog rada hrvatski izvoznici mogu podići svoju konkurentnost.

S druge strane, ograničenja ovog istraživanja odnose se na manji broj ispunjenih upitnika (133), što je dovelo do nedovoljnog uzorka za provođenje rangiranja i testiranja dokazivosti hipoteza za svaki pojedini sektor gospodarstva i za svaku pojedinu grupu poduzeća (broj zaposlenih, visina prihoda).

Uz navedeno, ograničenja istraživanja predstavljalo je i nepostojanje ovakvih i/ili sličnih istraživanja u Hrvatskoj i svijetu. 


\title{
THE ANALYSIS OF THE INFLUENCE OF THE FIVE PORTER FORCES ON THE COMPETITIVENESS OF CROATIAN EXPORT COMPANIES
}

\author{
Kristijan Marić, Ph.D., senior lecturer \\ Libertas International University \\ Trg J. F. Kennedy 6 b, 10000 Zagreb, Croatia \\ Mobile phone: +385 91 3888-305, e-mail: kristijan.maric1@gmail.com
}

\section{SUMMARY}

This paper discusses the competitiveness of the Croatian economy. In the theoretical chapters of the paper, secondary data sources are based on and collected by the desk research method. These chapters present the competitiveness of the Croatian economy and the concept of five competing forces according to Porte. For this purpose, scientific and professional literature and Internet sources were used. In addition to the secondary ones, the paper also presents the primary results of the research, which represent the answers of the respondents collected by the method of an online survey. Respondents were represented by employees of Croatian export companies, and their answers were processed by the method of descriptive statistical analysis. In this regard, the aim of the research in this paper is to rank the impact of Porter's five forces on the competitiveness of Croatian export companies, which was conducted by statistical analysis of variance. The subject of this research, with secondary and primary data presented in this paper, is taken from the doctoral dissertation of the author of this paper.

Keywords: five Porter forces; global competitiveness; Croatian competitiveness; Croatian exporters 


\section{LITERATURA}

1. Andrijanić, I. (2012). Poslovanje u vanjskoj trgovini. Zagreb: Mikrorad.

2. Tipurić, D. i suradnici (1999). Konkurentska sposobnost poduzeća. Zagreb: Sinergija.

3. IMD godišnjak svjetske konkurentnosti (2019). Preuzeto s: http://konkurentnost.hr/imd-godisnjak-svjetske-konkurentnosti-2019-stvarni-napredak-zahtijeva-brze-i-temeljitije-reforme/ (1.7.2019.)

4. Marić, K. (2019). Modeli za podizanje izvozne konkurentnosti hrvatskoga gospodarstva (doktorska disertacija, Sveučilište u Zadru i Sveučilište Libertas, Zagreb).

5. Porter, M. (2008). Konkurentska prednost. Zagreb: Masmedia. 